\title{
Do not forget decubitus view: a simple and useful tool in acute abdomen
}

\author{
Wei-Te Lei, ${ }^{1}$ Chi-Hone Lien, ${ }^{1}$ Yih-Cherng Duh, ${ }^{2}$ Chien-Yu Lin ${ }^{1}$ \\ ${ }^{1}$ Paediatrics Department, Hsinchu Mackay Memorial Hospital, Hsinchu, Taiwan, Province of China; \\ 2Paediatric Surgery Department, Hsinchu Mackay Memorial Hospital, Hsinchu, Taiwan, Province of China
}

Correspondence to Dr Chien-Yu Lin, mmhped.lin@gmail.com

\section{DESCRIPTION}

A 14-year-old boy presented to the emergency department with progressive abdominal pain for 1 week, which was epigastric, dull initially but then sharp in nature. Cold sweating, occasional vomiting, stressful life style were associated but no radiation pain was told. He was afebrile and denied drug consumption such as non-steroidal anti-inflammatory drug or Chinese herbs. At arrival, physical examination disclosed abdominal muscle guarding with board-like rigidity. Standing plain abdominal film showed no subphrenic free air (figure 1A). Perforated peptic ulcer with peritonitis was still highly suspected and further decubitus film revealed pneumoperitoneum (figure $1 \mathrm{~B}$, arrows). Timely laparotomy confirmed the diagnosis of perforated peptic ulcer with perforation over the anterior wall of pyloric ring. An erect chest or abdominal radiograph is the first choice in approaching acute abdomen and early detection of organ perforation is important. However, free intraperitoneal air is not always visible initially and the decubitus view may offer a more convenient, rapid, non-invasive, cheap and less radiation exposure investigating tool at the emergency department, comparing with the CT. ${ }^{1}$ In the era of high technology, the primary healthcare provider should be more confident of clinical judgment, even there is no air in the first radiograph.

Competing interests None.

Patient consent Obtained.

\section{REFERENCES}

1. Grassi R, Romano S, Pinto A, et al. Gastro-duodenal perforations: conventional plain film, US and CT findings in 166 consecutive patients. Eur J Radiol 2004;50:30-6.

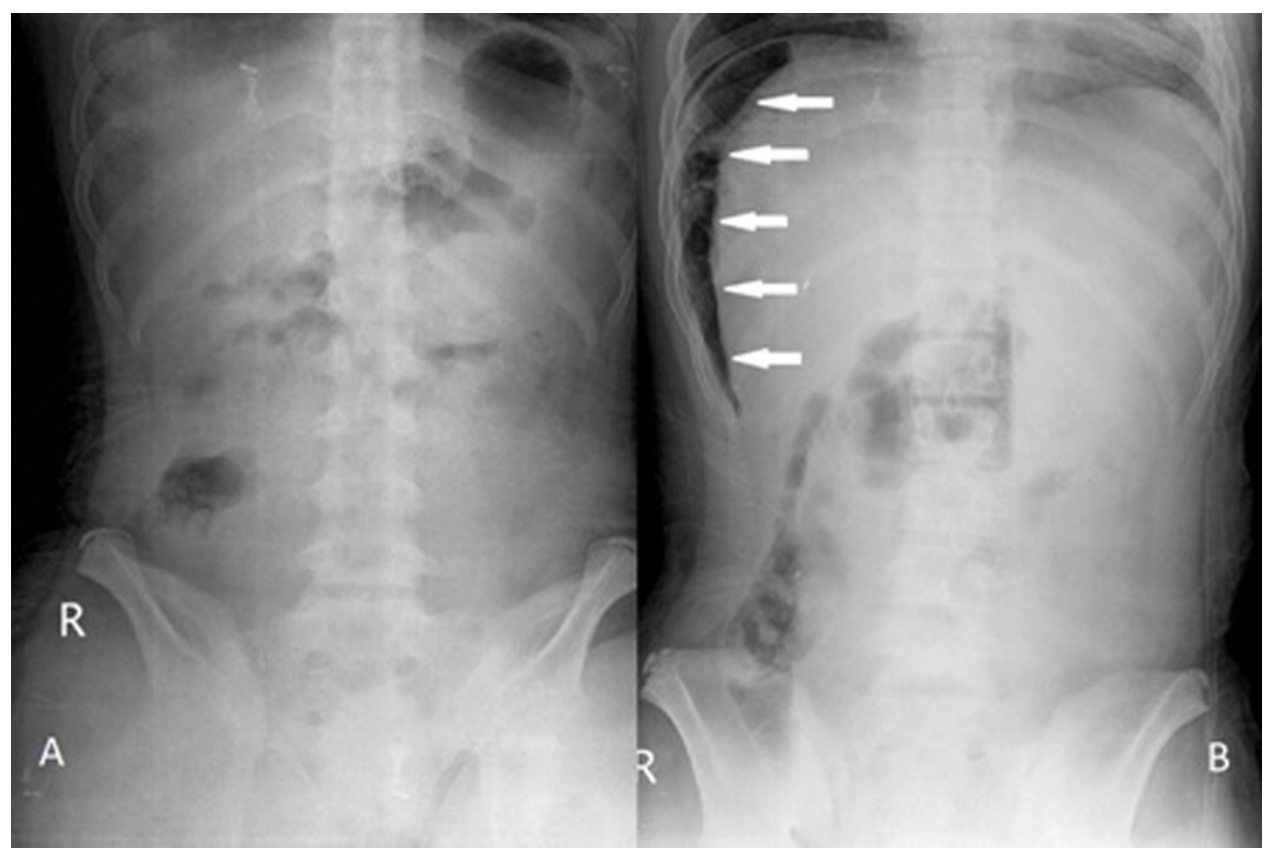

Figure 1 (A) Plain film of abdomen showed no subphrenic free air. (B) The lateral decubitus view of abdomen revealed intraperitoneal free air (arrows). 


\section{BMJ Case Reports}

This pdf has been created automatically from the final edited text and images.

Copyright 2011 BMJ Publishing Group. All rights reserved. For permission to reuse any of this content visit http://group.bmj.com/group/rights-licensing/permissions.

BMJ Case Report Fellows may re-use this article for personal use and teaching without any further permission.

Please cite this article as follows (you will need to access the article online to obtain the date of publication).

Lei WT, Lien CH, Duh YC, Lin CY. Do not forget decubitus view: a simple and useful tool in acute abdomen. BMJ Case Reports 2011;

10.1136/bcr.10.2011.4893, date of publication

Become a Fellow of BMJ Case Reports today and you can:

- Submit as many cases as you like

- Enjoy fast sympathetic peer review and rapid publication of accepted articles

- Access all the published articles

- Re-use any of the published material for personal use and teaching without further permission

For information on Institutional Fellowships contact consortiasales@bmjgroup.com

Visit casereports.bmj.com for more articles like this and to become a Fellow 